\title{
KEBERADAAN RUMAH SINGGAH DALAM PEMENUHAN HAK-HAK ANAK JALANAN
}

\author{
Fransiska Novita Eleanora \\ Fakultas Hukum, Universitas Bhayangkara Jakarta Raya, Indonesia \\ Email : fransiska.novita@dsn.ubharajaya.ac.id
}

\section{Melanie Pita Lestari}

Fakultas Hukum, Universitas Bhayangkara Jakarta Raya, Indonesia Email : melanie.pita@dsn.ubharajaya.ac.id

\author{
Zulkifli Ismail \\ Fakultas Hukum, Universitas Bhayangkara Jakarta Raya, Indonesia \\ Email : zulkifli.ismail@dsn.ubharajaya.ac.id
}

\begin{abstract}
ABSTRAK
Tujuan penelitian adalah untuk mengetahui keberadaan rumah singgah dalam memberikan perlindungan terhadap hak-hak anak jalanan serta kendala yang dihadapinya. Metode dalam Penelitian ini adalah penelitian yuridis normatif dengan berdasarkan pada konsep dan asas serta mengacu pada literatur-literatur dan peraturan akan perundang-undangan. Hasil penelitian menunjukan keberadaan rumah singgah menjadi salah satu bentuk perlindungan terhadap anak dengan melaksanakan rehabilitasi sosial dan jaminan sosial bagi anak-anak sebagai korban tindak pidana dan anak-anak yang mengalami trauma, keberadaan rumah singgah ini juga agar anak-anak mendapatkan pembinaan, pendidikan serta pelayanan kerohanian sehingga tetap mendapatkan hak-haknya dan mendapatkan perlindungan serta kesejahteraan. Kendala yang dihadapi terkait keberadaan rumah singgah yaitu mencakup kurangnya sumber daya manusia atau personil-personil yang handal dalam pengelolaan rumah singgah, belum terwujudnya kemudahan akses bagi ruma-rumah singgah mengingat keberadaannya dilokasi yang relatif agak jauh dari kantong aktifitas anak-anak jalanan yang menjadi warga binaannya, sarana dan prasarana masih kurang sehingga masih dibutuhkan adanya pihak manajeman yang profesional juga dalam menata setiap ruangan pembelajaran yang profesional dibidangnya, kurangnya dukungan masyarakat terhadap keberadaan rumah singgah, dikarenakan ketidakperdulian dan dengan sikap cuek terhadap keberadaan atau kehadiran anak-anak jalanan di sekitar lingkungannya.
\end{abstract}

Kata Kunci: Anak Jalanan; Pemenuhan Hak Anak; Rumah Singgah.

\section{ABSTRACT}

The research objective was to determine the existence of open houses in protecting the rights of street children and the obstacles they face. The method in this study is a normative juridical study based on concepts and principles and refers to the literature and legislation. The results showed that the existence of open houses is a form of protection for children by implementing social rehabilitation and social security for children as victims of crime and children who have experienced trauma. spiritual services so that they still get their rights and get protection and welfare. The obstacles faced related to the existence of open houses include the lack of human resources or reliable personnel in managing open houses, the lack of easy access for open houses, considering that they are located relatively far from the pockets of activities of street children who are residents. under their guidance, the facilities and infrastructure are still lacking so there is still a need for professional management in arranging every professional learning room in their field, lack of community support for the existence of a halfway house, due to indifference and indifference to the presence or presence of street children around their environment .

Keywords: Street Children; Fulfillment of Children's Rights; Halfway house. 


\section{A. PENDAHULUAN}

Salah satu Implementasi sebagai Negara yang berdasarkan hukum adalah adanya perlindungan dan pengakuan serta menghormati akan keberadaan hak dari manusia yaitu hak dasarnya termasuk juga hak asasi anak serta menjunjung tinggi peradilan yang benar dan tidak memihak, ini diartikan bahwa adanya jaminan akan keberadaan akan hak setiap orang.

Undang-Undang Dasar Negara Republik Indonesia Tahun 1945 (UUD NRI 1945) Pasal 34 menyebutkan bahwa fakir miskin dan anak terlantar di pelihara oleh Negara, hal ini dapat diartikan bahwa anak jalanan berhak hidup layak sebagaimana anak-anak pada umumnya, adanya perlindungan terhadap hak anak jalanan yang didapatkan dan diberikan kepadanya tanpa adanya perbedaan atau diskriminasi Di sebut sebagai anak jalanan karena kecenderungan banyak menghabiskan waktunya di jalanan, padahal kalau diperhatikan usia mereka beragam sekali dibawah 18 tahun sesuai dengan pengertian anak, tetapi karena kondisi dari kehidupan ekonomi sehingga anak diharuskan untuk bekerja dalam memenuhi kebutuhan hidupnya.

Pengakuan dan jaminan hak juga sudah ada pengaturannya di dalam ketentuan tentang undang-undang mengenai hak asasi manusia yaitu Undang-Undang Nomor 39 Tahun 1999 tentang Hak Asasi Manusia. Ketentuan undang-undang ini juga berlaku bagi anak sebagaimana adanya aturannya dalam undang-undang perlindungan anak, dikarenakan masalah perlindungan anak merupakan masalah yang kompleks, dan bukan hanya anak-anak pada umumnya tetapi anak yang bisa dikatakan hidupnya di jalanan dengan mencari kehidupannya belum lagi banyaknya kejahatan-kejahatan yang terjadi yang harus dialaminya. ${ }^{1}$

Kondisi yang demikian sering mengakibatkan anak dapat terpengaruh untuk melakukan tindakan yang benar, tindak pidana, kekerasan dijalanan sangat mempengaruhi kehidupan anak tersebut, padahal seorang anak wajib untuk mendapatkan pendidikan dan belajar di sekolah bukan bekerja yang belum sepatutnya dilakukannya, ini dikatakan adanya keterpaksaan dan himpitan kehidupan dan kemiskinan. Perlindungan seperti disebutkan dalam ketentuan UUD 1945 tidak hanya menjadi tanggungjawab Negara saja, melainkan seluruh masyarakat ikut ambil bagian dalam memberikan perlindungan, selain adanya bidang dalam pendiidkan juga bentuk dari perlindungan yang lainnya dengan bantuan akan hukum manakala anak menjadi korban dan juga pelaku dari tindak pidana yang terjadi, tetap diperlakukan sama dalam haknya ${ }^{2}$. Anak jalanan sebagai masalah sosial ditangani oleh dinas sosial dalam kaitannya dengan rumah singgah dimana tujuan dibentuknya rumah singgah agar dapat merealisasikan nilai-nilai dan juga berlaku serta dapat mengatasi dan membantu terhadap masalah-masalah kehidupan dari anak-anak jalanan dalam memenuhi akan kebutuhan dari hidupnya ${ }^{3}$.

Keberadaan rumah singgah memberikan ruang bagi anak-anak jalanan untuk dapat mencari dan menemukan solusi bagaimana dan makna atau arti kehidupannya, mencari alternatif serta jalan keluar, bagi mereka yang sudah tidak dapat menemukan solusinya. Keberadaan rumah singgah memberikan kesejukan kepada anak terlantar untuk serasa menemukan keluarganya, anak jalanan tersebut hanyalah sebagai korban dalam konflik keluarga, dalam rumah singgah ini juga bertujuan utama dalam menghapuskan stigma kepada anak jalanan agar tidak dianggap jelek dalam masyarakat karena sudah berkeliaran di jalan apalagi jika sampai menjadi pelaku kejahatan atau tindak pidana, dengan adanya rumah singgah yang dilengkapi dengan berbagai program pembinaan, pelayanan dan pendidikan bisa menbawa pengaruh yang tentunya memberikan sikap positif serta baik bagi pertumbuhan dan perkembangan anak,

${ }^{1}$ Darwin Prints. (2001). Sosialisasi dan Diseminasi Penegakan Hak Asasi Manusia. Bandung: P.T. Citra Aditya Bakti, hlm. 31-33

${ }^{2}$ B. Waluyo. (2008). Pidana dan Pemidanaan. Jakarta: Sinar Grafika, hlm. 16

${ }^{3}$ https://republika.co.id/berita/p2nioq284/rumah-singgah-mengentas-anak-jalanan"rumah singgah mengentas anak jalanan" diakses, 20 Agustus 2020, Pukul16.39 WIB 
serta memberikan anak suatu stigma yang baik di tengah-tengah pergaulan dan tidak merusak mentak dan kejiwaannya ${ }^{4}$.

Fokus permasalahan dalam penelitian adalah keberadaan rumah singgah dalam memberikan perlindungan terhadap hak-hak anak jalanan serta kendala yang dihadapinya, serta kendala yang dihadapi.

\section{B. METODE PENELITIAN}

Penelitian ini menggunakan yuridis normatif dengan pendekatan peraturan perundangundangan dan konseptual. Maka dari itu, mengacu kepada asas-asas dari hukum atau konsepkonsep dan juga berkaitan dengan teori-teori serta literatur-literatur ataupun juga buku-buku dan juga peraturan perundang-undangan yang relevan dengan masalah yang diteliti, dan juga penelitian yang yuridis normatif ini menelaah studi dari kepustakaan.

\section{PEMBAHASAN}

\section{Anak Jalanan}

Istilah anak jalanan, dalam Konstitusi sepadan dengan pengaturan Pasal 34 UUD NRI yang menyebutkan bahwa fakir miskin dan anak terlantar di pelihara oleh Negara. Anaka terlantar adalah mereka yang mencari nafkah dijalanan dan menghabiskan waktunya seluruhnya atau sebagian ditempat yang umum untuk berkeliaran dan mencari nafkah dalam hidupnya. Adanya kerelaan untuk menghidupi dirinya dengan berusaha melakukan kegiatan dan mencari akan nafkah dengan keinginan sendiri dan ada juga karena disuruh atau dipaksa dipaksa untuk dapat bekerja di jalanan disebabkan karena ekonomi yang rendah. ${ }^{5}$

\section{Penyebab Terjadinya Anak Jalanan}

a) lari dari keluarga, dikarenakan anak merasa tidak ada kenyamanan sehingga banyak menghabiskan waktu diluar rumah, dan akibatnya anak mendapatkan keluarga baru yang kadangkala tidak memberikan kedamaian baginya malah sebaliknya

b) asal mulanya dari keluarga terlantar, masa lalu dari kehidupan seorang anak biasanya menjadikananakuntukselaluinginbebasdanhidupdijalanandantidakdapatmengendalikan dirinya serta mengikuti aturan yang ada (selalu ingin hidup di jalanan)

c) keluarga besar melemah, suatu keluarga yang sudah dibangun tiba-tiba kandas dikarenakan masalah ekonomi, dan perceraian atau perpisahan diantara orangtuanya serta kemiskinan, mengakibatkan anak menjadi terkatung-katung dan hidupnya tidak jelas, dan tidak tahu dimana ia tinggal sehingga akhirnya memilih untuk hidup dijalanan.

d) kesenjangan komunikasi antara orangtua dan anak, kesibukan dari orangtua yang begitu padat karena pekerjaan, tidak menyediakan waktu luang bagi anaknya untuk bertemu dan bercanda, tetapi hanya bekerja dan mencari uang, hasilnya tidak mengetahui perbuatan dan tingkah laku anaknya.

e) keluarga miskin, dikarenakan ketidakmampuan berasal dari keluarga sehingga anak seringkali membantu orangtuanya untuk memenuhi kehidupanya dengan bekerja, salah satunya yang sering terjadi menjadi pengamen di jalanan.

f) perceraian serta kehilangan orangtuanya

${ }^{4}$ https://mediaindonesia.com/read/detail/36877-pemerintah-daerah-diminta-turun-untuk-tangani-anak-jalanan "Pemerintah Daerah di Minta Turun Tangani Anak Jalanan" diakses 21 Agustus 2020, Pukul 17/06 WIB

${ }^{5}$ Depsos. (1999). Petunjuk Pelaksanaan Pembinaan Kesejahteraan Sosial Anak Jalanan, Jakarta, hlm. 26 
Mengakibatkan anak hidup dalam ketidakjelasan, perceraian dapat mengakibatkan trauma kepadaanak, danuntukmenghilangkantraumatersebutdanbanyakmenghabiskanwaktunya di luar'.

g) kekerasan yang terjadi dalam keluarga

kekerasan menjadi penyebabterjadinya keretakan hubungan antara orang tua dengananaknya, karena kekerasan mengakibatkan anak lari dari rumah dan mencari rumah atau tempat tinggalnya di jalanan.

h) keterbatasan ruang dalam rumah, rumah dengan ruangan yang sempit dan terbatas mengakibatkan terbatasnya ruang gerak sehingga mencari kenyamanan di luar rumah

i) eksploitasi dilakukan secara ekonomi, dengan melakukan cara-cara yang ilegal yakni menjual atau memperdagangkan dirinya untuk memenuhi kebutuhan akan hidupnya atau mempertahankan kehidupannya.

j) keluarga yang homeless, dikarenakan tidak berkemampuan memiliki suatu tempat tinggal, sehingga harus menumpang dan tinggal bersama dengan teman, atau kerabat, bahkan dengan keluarga lainnya. ${ }^{7}$

\section{Perlindungan Anak}

Segala sesuatu yang berkaitan dengan kegiatan untuk dan dalam menjamin dan juga dalam melindungi anak dan juga keberadaan akan hak-haknya untuk selalu dapat hidup, serta dapat tumbuh dan juga berkembang serta ikut berpartisipasi sesuai dengan martabat akan kemanusiaan dan juga harkatnya anak secara optimal, dan mendapat perlindungan dari tindakan kekerasan dan juga dari tindakan yang diskriminasi.

\section{Penyelenggaraan Perlindungan Hak Anak}

Penyelenggaraan terhadap perlindungan akan anak dan hakya dapat dilaksanakan melalui ;

1. Perlindungan di bidang Agama

2. Perlindungan di bidang Kesehatan

3. Perlindungan di bidang Pendidikan

4. Perlindungan di bidang Sosial

5. Perlindungan di bidang Khusus. ${ }^{8}$

\section{Bentuk-Bentuk Perlindungan Terhadap Anak Jalanan}

a) Upaya rehabilitasi, dapat di lakukan melalui lembaga dari dalam juga dari luar, diman usaha yang dilakukan bertujuan memulihkan kondisi, mental dan juga fisik lainnya. Akibat dati trauma yang menimpanya akibat suatu peristiwa pidana yang sudah menimpanya.

b) Nama baik dari korban dan juga keluarganya diberikan perlindungan agar identitasnya tidak jelek maupun tercemar, dihadapan publik.

c) Upayadalammemberikansuatujaminan terhadapkeselamatankepadasaksikorbanterhadap hal ini anak dan juga saksi ahli, baik berupa fisik, juga mental ataupun terhadap sosialnya dari segla ancaman dari berbagai pihak, dengan mengupayakan agar segala proses dari perkaranya dapat berjalan secara efisien.

\footnotetext{
${ }^{6}$ Abu Huraerah. (2006). Kekerasan Pada Anak, Bandung: Nuansa, hlm. 78

${ }^{7}$ Ibid, hlm. 34

${ }^{8}$ Ibid, hlm. 61
} 
d) Perkembangan dari akan adanya proses terhadap perkaranya, merupakan pemberian yang aksebilitas dan bertujuan mendapatkan informasi baik dari pihak korban sendiri maupn keluarganya9.

\section{Keberadaan Rumah Singgah Terhadap Anak Jalanan}

a. Program Pembinaan

Programini diberikan dalambentukyangkerohaniaan, dan ditinjau daripendekatan dalam aspek agama dimana agar anak jalanan dicegah dan jangan sampai melakukan perbuatan yang dianggap melanggar atau dilarang oleh agama, tetapi bagi yang sudah terjerumus di upayakan untuk memyadarkan dirinya agr tidak terulang kembali perbuatannya ${ }^{10}$.

b. Program Pelayanan

Dilaksanakan melalui pengobatan, dan rehabilitasi bagi anak yang mengalami luka-luka dan juga trauma selain adanya koordinasi dengan dinas sosial juga ada kerjasama dengan berbagai lembaga lainnya yang berkompeten terhadap anak seperti Komisi Perlindungan Anak Indonesia (KPAI) dan juga Komisi Nasional Anak (KOMNAS ANAK)

c. Program Pendidikan

Mendorong agar anak besekolah atau melanjutkan sekolahnya serta mengulang kembali pelajarannya di rumah, ini dan melakukan monitoring agar anak dapat melanjutkan pendidikannya dengan baik

\section{Peraturan Tentang Anak Jalanan}

(a)Undang-Undang Republik Indonesia Nomor 4 Tahun 1979 tentang Kesejahteraan Anak

(b)Undang-Undang Republik Indonesia Nomor 11 Tahun 2009 tentang Kesejahteraan Sosial

(c)Undang-Undang Nomor 23 Tahun 2002 tentang Perlindungan Anak

(d)Undang-Undang Nomor 35 Tahun 2014 tentang perubahan Undang-Undang Nomor 23 Tahun 2002 tentang Perlindungan Anak

(e)Undang-Undang Republik Indonesia Tentang Nomor 39 Tahun 1999 Tentang Hak Asasi Manusia Tahun 1999

\section{Perlindungan Terhadap Anak Jalanan Terkait Dengan Keberadaan Rumah Singgah}

Perlindungan akan hak-hak semua orang adalah kewajiban dari Negara untuk memberikan perlindungan kepada warganya terkait akan hak-hak yang harus dilindungi termasuk juga ha-hak hidup, pendidikan dan pengajaran, kesehatan, rekreasi dan masih banyak lagi dan semuanya itu termasuk hak-hak anak dalam arti perlindungan akan haknya jika keberadaan di jalanan dapat mengakibatkan anak menjadi pelaku ataupun korban dari suatu perbuatan akan tindak pidana yang telah terjadi baik disengaja atau tidak disengaja yang anak dijadikan sebagai pelaku atau korban ${ }^{11}$

Dalam ketentuan yang terdapat dalam Undang-undang tentang Perlindungan Anak orangperorangan yang menderita musibah dan tidak mempunyai kehidupan yang layak serta mempunyai masalah-masalah sosial. Secara terperinci dalam ketentuan pasal ke-5 ayatnya yang ke-2 bahwa yang disebut sebagai masalah sosial adalah dikarenakan adanya kemiskinan,

\footnotetext{
${ }^{9}$ Damanhuri Warganegara. (2017). Perlindungan Hukum Terhadap Anak Jalanan (Jurnal), Fakultas Hukum, Universitas Lampung, Bandar Lampung, hlm. 5-6

${ }^{10}$ Daniel. Silistyarini, Supriadi. (2013). Pembinaan Anak Jalanan Melalui Rumah Singgah Holidi Kelurahan Tanjung Hilir Kecamatan Pontianak Utara, Jurnal Pendidikan dan Pembelajaran Khatulistiwa, Vol. 2 (12), hlm. 5

${ }^{11}$ Ibid., hlm. 23
} 
adanya ketelantaran dan tidak mempunyai tempat tinggal yang jelas, kecacatan baik yang dibawa sejak lahir atau juga tidak, keterpencilan hidup yang jauh dari keramaian dan tidak bisa bergaul dengan lingkungan masyarakatnya, terjadinya perilaku yang menyimpang, dan korban yang menderita akibat dari suatu bencana alam dan tidak memiliki tempat tinggal hidup dalam penampungan dan sebagai gelendangan di jalan, serta korban dikarenakan adanya tindakan kekerasan yang dialaminya, eksploitasi baik secara seksual dan juga ekonomi, dan mendapatkan perlakuan diskriminasi atau salah dalam memperlakukan anak ${ }^{12}$.

Masalah sosial tersebut berhak di berikan perlindungan akan hak-haknya anak terkait perlindungan hukumnya, yaitu penyediaan adanya rumah singgah yang disediakan dalam rangka penyelenggaraan kesejahteraan sosial yakni dengan merehabilitasi sosial sebagai korban dari anak-anak jalanan yang sebagian hidupnya dihabiskan dijalanan tentunya tidak luput dari kekerasan fisik dan seksual yang diterimanya, dengan pemberian rehabilitasi sosial didalam rumah singgah selain dapat mengobati luka-lukanya akibat kekerasan yang dialami korban dari pelaku, tetapi juga korban direhabilitasi sosial agar keberadaannya dan dalam dirinya tidak merasa takut, malu dan minder kembali ke lingkungannya ataupun merasa rendah diri akibat pernah menjadi korban atau sasaran dari tindak pidana yang dialaminya.

Hak-hak anak sebagaimana juga diatur dalam ketentuan dari Undang-Undang Nomor 35 Tahun 2014 tentang perubahan Undang-Undang Nomor 23 Tahun 2002 tentang Perlindungan Anak juga menyebutkan bahwa anak-anak berhak mendapatkan perlindungan akan tindakantindakan yang dialamainya yang mengakibatkan anak sebagai korban dari suatu tindak pidana yang terjadi, selain itu di dalam ketentuan Pasal 9 ayat (1) undang-undang perlindungan anak ini "Setiap anak juga berhak dalam memperoleh akan pendidikan dan juga pengajaran dalam rangka adanya pengembangan akan pribadinya sendiri dan juga pada tingkat kecerdasannya yang sesuai dan juga dengan adanya minat dan bakatnya".

Pemenuhan akan adanya pendidikan itu haruslah dapat memperhatikan aspek adanya perkembangan yang juga fisik dan juga mental mereka. Sebab, dikatakan sebagai seorang anak bukanlah dalam arti orang yang sudah dewasa dewasa yang masih berukuran kecil, serta mereka mempunyai akan dunianya yang sendiri dan tentunya sangat berbeda juga dengan orang dewasa ${ }^{13}$. Tidak cukup dalam memberinya suapan makanan dan minuman saja, atau hanya sebatas melindunginya di dalam sebuah rumah, bahkan lebih dari semua itu karena anak sangat membutuhkan kasih sayang, dan belaia dari kasih sayang yang didapatkannya adalah sangat fundamen dari suatu pendidikan. Tanpa adanya rasa kasih dan juga suatu pendidikan yang ideal tak mungkin dapat dijalankan. Ibarat dari peribahasa mengatakan bahwa pendidikan tanpa adanya cinta kasih seperti adanya nasi tanpa lauk, menjadi kering dan hambar, dan juga tidak menarik ${ }^{14}$.

Peran dan juga fungsi dari rumah singgah bagi program pemberdayaan dari anak-anak jalanan dapat dikatakan sesuatu yang sangatlah penting, di karenakan :

a) Sebagai tempat akan adanya perlindungan yang ada dari berbagai segala bentuk-bentuk kekerasanyangmemang kerapkali selalu menimpa akan keberadaan darianak-anakjalanan dari segala kekerasan dan adanya prilaku penyimpangan secara seksual ataupun adanya berbagai bentuk-bentuk dari kekerasan yang lainnya.

b) Rehabilitasi, yaitu mengembalikan serta dan juga menanamkan akan fungsi sosial dari anak.

\footnotetext{
${ }^{12}$ Rahman A, 2005, Eksploitasi Orang Tua Terhadap Anak dengan Mempekerjakan Sebagai Buruh, Jurnal Sodality, Vol. 5 (2) hlm. 17

${ }^{13}$ Sri Mugianti, Sri Winarni, Wuandari Dyah Pangestuti. (2018). Faktor Penyebab Remaja Menjadi Anak Jalanan, Jurnal Pendidikan Kesehatan, Vol. 7 (1), hlm. 27

${ }^{14}$ Ninik Yuniarti. (2012). Eksploitasi Anak Jalanan Sebagai Pengamen dan Pengenis di Terminal Tidar Oleh Keluarga, Komunitas, Vol. 4 (2), hlm. 211
} 
c) Pelayanan yang memberikan akses, yang bersifat persinggahan yang sementara dan sekaligus juga akan akses kepada berbagai bentuk pelayanan yang bersifat sosial seperti halnya pendidikan, dan juga kesehatan dll. Dimana lokasi akan keberadaan dari tempat / rumah singgah harus selayaknya berada selalu berada ditengah-tengah masyarakat karena memudahkan terhadap proses terhadap pendidikan yang sejak dini, dan juga adanya suatu penanaman terhadap adanya norma dan resosialisasi yang ditujukan bagi kehidupan akan anak-anak dijalanan. Sehingga dalam keberadaan rumah singgah adanya program-program pelayanan, pembinaan, yang diberikan kepada anak-anak jalanan yang berhak untuk mendapatkan hak-haknya, seperti anak-anak pada umumnya ${ }^{15}$.

Ketentuan Undang-Undang Nomor 39 Tahun 1999 Tentang Hak Asasi Manusia (HAM), sudah mengatur akan keberadaan hak-hak setiap orang sejak dilahirkan karena hak anak tanpa terkecuali merupakan hak dan jaminan setiap orang untuk melindungi anak-anak termasuk hak-hak anak di jalanan, sehingga siapapun orang dewasa harus peduli dan peka terhadap keberadaan akan anak-anak di jalanan yang memang membutuhkan perlindungan akan hakhaknya.

\section{Kendala Yang di hadapi Terkait Keberadaan Rumah Singgah Bagi Anak Jalanan}

Kendala disebut juga sebagai hambatan dalam suatu proses atau pelaksanaan sehingga apa yang sudah dilakukan tidak berjalan seperti adanya atau tidak berjalan lancar seperti yang di harapkan. Keberadaan rumah singgah yang diperuntukkan bagi anak-anak jalanan yaitu :

a) Kurangnya sumber daya manusia atau personil-personil yang handal dalam pengelolaan rumah singgah. ${ }^{16}$

b) Belumterwujudnyakemudahan akses bagiruma-rumahsinggahmengingatkeberadaannya dilokasi yang relatif agak jauh dari kantong aktifitas anak-anak jalanan yang menjadi warga binaannya. Hal ini menunjukkan bahwa prinsip pelayanan publik belum sepenuhnya menjangkau kepentingan pengguna manfaat, padahal sebagai pelayanan publik harus ada 10 (sepuluh) prinsip pelayaman publik yang terdiri dari :

- Kesederhanaan, prosedur dalam meberikan pelayanan harus jelas dan tidak berbelitbelit

- Kejelasan, dalam meberikan penjelasan dalam menghadapi persoalan dari masyarakat ataupun anakanak di dalam rumah singgah

- Kepastian Waktu, konsistensi dan penyelesaiannya harus sesuai dnegan waktu yang telah ditentukan

- Akurasi, dimana produk dari suatu pelayanan publik dapat diterima secata baik, juga benar dan tepat serta sah

- Keamanan dan proses akan kepastian hukum

- Tanggungjawab dari pimpina pelayana publik yang ditunjuk untuk bertanggungjawab penuh terhadap proses pelaksanaan pekerjaan.

- Kelengkapan saranna dan prasarana yang mendukung termasuk juga sarana terhadap akan pendukung yang lainnya yang sudah memadai yakni teknologi, dan telekomunikasi dan juga informatika

\footnotetext{
${ }^{15}$ Syahril. (2006). Kajian Terhadap Kehidupan Perilaku dan Perilaku Anak-Anak Jalanan Serta Dampak Sosial yang Ditimbulkannya, Jurnal Kependidikan, Triadik Vol. 9 (2), hlm. 122

${ }^{16}$ Ristiyani, Muhammad Noor Ahsin. (2017). Validitas Buku Santun Berbahasa Untuk Interaksi Pengasuhan Berbahasa Anak Jalanan di Rumah Singgah, Transformatika, Jurnal Bahasa, Sastra dan Pengajarannya, Vol. 1 (2), hlm. 248
} 
- Kemudahan dalam mendapatkan akses yang mudah dan masyarakat dapat menjangkaunya denga menyediakan sarana baik komunikasi dan juga informatika

- Sikap kedisiplinan, keramahan dan kseopanan dalam memberika pelayanan publik kepada masyarakat

- Kenyamanan dimana kondisi lingkungan harus bersih dan tertib, disediakan rumah tangga yang nyaman bersih, juga ada toilet, tempat ibadah, parkir dan sebagainya. ${ }^{17}$

c) Sarana dan prasarana masih kurang sehingga masih dibutuhkan adanya pihak manajeman yang profesional juga dalam menata setiap ruangan pembelajaran yang profesional dibidangnya. ${ }^{18}$

\section{KESIMPULAN}

Keberadaan rumah singgah menjadi salah satu bentuk perlindungan terhadap anak dengan melaksanakan rehabilitasi sosial dan jaminan sosial bagi anak-anak sebagai korban tindak pidana dan anak-anak yang mengalami trauma, keberadaan rumah singgah ini juga agar anak-anak mendapatkan pembinaan, pendidikan serta pelayanan kerohanian sehingga tetap mendapatkan hak-haknya dan mendapatkan perlindungan serta kesejahteraan. Kendala yang dihadapi terkait keberadaan rumah singgah yaitu mencakup kurangnya sumber daya manusia atau personil-personil yang handal dalam pengelolaan rumah singgah, belum terwujudnya kemudahan akses bagi ruma-rumah singgah mengingat keberadaannya dilokasi yang relatif agak jauh dari kantong aktifitas anak-anak jalanan yang menjadi warga binaannya, sarana dan prasarana masih kurang sehingga masih dibutuhkan adanya pihak manajeman yang profesional juga dalam menata setiap ruangan pembelajaran yang profesional dibidangnya, kurangnya dukungan masyarakat terhadap keberadaan rumah singgah, dikarenakan ketidakperdulian dan dengan sikap cuek terhadap keberadaan atau kehadiran anak-anak jalanan di sekitar lingkungannya.

\section{DAFTAR PUSTAKA}

\section{Buku}

Abu Huraerah. (2006). Kekerasan Pada Anak, Nuansa, Bandung.

B. Waluyo. (2008). Pidana dan Pemidanaan, Sinar Grafika, Jakarta

Daniel. Silistyarini, Supriadi. (2013). Pembinaan Anak Jalanan Melalui Rumah Singgah Holidi Kelurahan Tanjung Hilir Kecamatan Pontianak Utara, Jurnal Pendidikan dan Pembelajaran Khatulistiwa, Vol. 2 (12)

Darwin Prints. (2001). Sosialisasi dan Diseminasi Penegakan Hak Asasi Manusia, P.T. Citra Aditya Bakti, Bandung

Damanhuri Warganegara. (2017). Perlindungan Hukum Terhadap Anak Jalanan, Jurnal Fakultas Hukum, Universitas Lampung, Bandar Lampung

Depsos. (1999). Petunjuk Pelaksanaan Pembinaan Kesejahteraan Sosial Anak Jalanan, Jakarta

Ninik Yuniarti. (2012). Eksploitasi Anak Jalanan Sebagai Pengamen dan Pengenis di Terminal Tidar Oleh Keluarga, Komunitas, International Journal of Indonesian Society and Culture, Vol. 4 (2)

\footnotetext{
${ }^{17}$ Suyatna. (2011). Revitaslisasi Model Penanganan Anak Jalanan di Rumah Singgah, Jurnal Ilmu Sosial dan Politik, Vol. 15 (1), hlm. 43 ${ }^{18}$ Ibid.
} 


\section{[JATISWARA] [Vol. 35 No. 3 November 2020]}

Rahman A. (2005). Eksploitasi Orang Tua Terhadap Anak dengan Mempekerjakan Sebagai Buruh, Jurnal Sodality, Vol. 5 (2)

Ristiyani, Muhammad Noor Ahsin. (2017). Validitas Buku Santun Berbahasa Untuk Interaksi Pengasuhan Berbahasa Anak Jalanan di Rumah Singgah, Transformatika, Jurnal Bahasa, Sastra dan Pengajarannya, Vol. 1 (2)

Sri Mugianti, Sri Winarni, Wuandari Dyah Pangestuti. (2018). Faktor Penyebab Remaja Menjadi Anak Jalanan, Jurnal Pendidikan Kesehatan, Vol. 7 (1)

Syahril. (2006). Kajian Terhadap Kehidupan Perilaku dan Perilaku Anak-Anak Jalanan Serta Dampak Sosial yang Ditimbulkannya, Jurnal Kependidikan, Triadik Vol. 9 (2)

Suyatna. (2011). Revitaslisasi Model Penanganan Anak Jalanan di Rumah Singgah, Jurnal Ilmu Sosial dan Politik, Vol. 15 (1)

\section{Peraturan Perundang-Undangan}

Undang-Undang Dasar Negara Republik Indonesia Tahun 1945

Undang-Undang Nomor 39 Tahun 1999 tentang Hak Asasi Manusia

Undang-Undang Nomor 35 tahun 2014 tentang Perubahan Undang-Undang Nomor 23 tahun 2002 tentang Perlindungan Anak

Undang-Undang Republik Indonesia Nomor 4 Tahun 1979 tentang Kesejahteraan Anak

Undang-Undang Republik Indonesia Nomor 11 Tahun 2009 tentang Kesejahteraan Sosial

\section{Internet}

https://republika.co.id/berita/p2nioq284/rumah-singgah-mengentas-anak-jalanan"rumah singgah mengentas anak jalanan" diakses, 20 Agustus 2020, Pukul 16.39 WIB

https://mediaindonesia.com/read/detail/36877-pemerintah-daerah-diminta-turun-untuktangani-anak-jalanan "Pemerintah Daerah di Minta Turun Tangani Anak Jalanan" diakses 21 Agustus 2020, Pukul 17.06 WIB 